\title{
Case Study Instruction In Educational Psychology Courses
}

Alyssa Gonzalez-DeHass, (E-mail: agonzale@fau.edu), Florida Atlantic University, Jupiter Patricia P. Willems, (E-mail: pwillems@fau.edu), Florida Atlantic University, Davie

\begin{abstract}
The case study method of instruction affords students the opportunity to see the real-world applications of what they are learning and to actively engage in problem-solving. The purpose of this study is to examine current research on the use of case- based instruction and consider how this method might be of benefit to students enrolled in educational psychology courses in either the traditional classroom or web-assisted learning environment.
\end{abstract}

\section{INTRODUCTION}

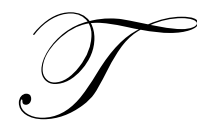

he case study method of instruction affords college students the opportunity to see the real-world applications of what they are learning (Grupe \& Jay, 2000), and the use of case studies has been proposed as a way for pre-professional teachers to actively engage in problem-solving for real-life situations (Wright \& Heeran, 2002). The purpose of this study is to examine current research on the use of casebased instruction and consider how this method might be of benefit to students enrolled in educational psychology courses in either the traditional classroom or web-assisted learning environment. Examining research conducted using the case-study method of teaching in educational psychology (Block, 1996; Bonk et al., 1998; Herman, 1998; Lundeberg, \& Scheurman, 1997), can be supplemented with research in other disciplines while investigating the merits of case-study use in the educational psychology coursework.

\section{OPPORTUNITY TO APPRECIATE COMPLEXITIES INVOLVED IN TEACHING}

Courses in educational psychology are often considered foundational knowledge for pre-service teachers enrolled in traditional teacher preparation programs. Often, students take these courses early in their academic programs, far in advance of their student teaching internship. However, it becomes increasingly apparent that teacher preparation programs should be exposing prospective teachers to the realities of classroom decision-making throughout their academic program. "What is becoming increasingly apparent is the developmental nature of learning to teach...The goals, methods, and philosophies of teacher education programs should address the needs of prospective teachers at various points in their development" (Harrington, 1995, pg. 203). "Effective P-12 classroom interventions may more likely occur if prospective teachers encounter teaching realities early in their preparation programs and learn how to translate the emerging knowledge base into professional practice." (Herman, 1998, pg. 391). Case studies can serve as facilitators for actual teaching experiences and represent a middle step between coursework and actual teaching experience. (Greenwood, Fillmer, \& Parkay, 2002).

"The life experiences of the majority of college students is often far removed from the realities faced by many of the individuals they will be responsible for serving in their professional lives" (Wright \& Heeren, 2002, pg. 114). Therefore, pre-service teachers often do not appreciate the complexities involved in teaching. Further, because of the diverse learning contexts, prospective teachers cannot come to understand the complexities of teaching through only the presentation of teaching methods and techniques (Harrington, 1995). Case studies provide an opportunity for prospective teachers to begin to understand the dilemmas teacher face on a daily basis. Researchers have proposed that for nursing students, case studies provide opportunities for students to actively experiment with solutions for these dilemmas within the safety of their coursework (DeMarco, Hayward, \& Lynch, 2002). The parallel is that such a safe environment would support learning for pre-service teachers. Teacher preparation programs might serve as classroom 
learning communities where prospective teachers, engaging in case-based instruction, might experience teacher decision-making of realistic classroom dilemmas with both teacher and peer support.

\section{REAL-WORLD APPLICATION OF CURRICULUM}

It has been said that learning and knowledge are situated in physical and social contexts, that the transfer and use of knowledge is affected by the context in which learning took place, and finally, that students often acquire decontextualized knowledge that they cannot use in everyday life because they lack the entrance into the community and the culture that uses such knowledge (Brown, Collins, \& Duguid, 1989). The traditional curriculum of educational psychology courses often includes abstract psychological concepts which at first glance may seem dispensable to prospective teachers until the utility of these theories is made apparent by grounding them in concrete teaching experiences. Instructors should supplement theoretical coverage with opportunities for application. Educational psychology courses have traditionally made too little provision for the application of theoretical knowledge and the development of professional decision making (Greenwood, Fillmer, \& Parkay, 2002). Case studies provide the forum for reflection and application of psychological concepts into classroom decision-making. "Learning to be systematic in decision-making and to be aware of cognitive processing during decision making takes just as much practice as acquiring relevant bodies of psychological, sociological, pedagogical, and organizational knowledge. In short, to be an effective decision maker, one needs to practice decision making....In education, it (case method) can provide the student with the opportunity to translate theories, principles, and methods into practice" (Greenwood, Fillmer, \& Parkay, 2002, pg. 281). Some educational psychology texts have included case studies; Block (1996) conducted an analysis of four different educational psychology texts use of case study materials to increase transfer and application. Her results showed that while the texts used different case-based activities they each had strong points as well as limitations in relation to potential for students' knowledge application when considering structural issues of placement within the text, instructional strategy used, and the content and structure of the text.

\section{ACTIVE LEARNING}

The case study approach encourages pre-service teachers to engage in active problem-solving rather than passively receiving theoretical content (Wright $\&$ Heeren, 2002). Across subject matter disciplines, case studies help students to see real applications of their class work while placing the bulk of the responsibility on the student to analyze situation of offer solutions (Grupe \& Jay, 2000). Researchers have often likened case study instruction to that of problem-based learning (PBL) (DeMarco, Hayward, \& Lynch, 2002, Wright \& Heeren, 2002). PBL refers to students acquiring knowledge and skills through real-life problems that are presented in context with the support of teachers and experts (Hung, 2002) and occurs as a result of students' efforts to solve a complex problem by identifying their own learning needs, locating resources to meet those needs, and applying what they have learned to the problem situation (Pedersen \& Liu, 2002). As Aspy, Aspy, and Quinby (1993) reveal, for the last twenty years, medical schools have explored alternative ways of educating future physicians, and what they have learned about PBL should be important for all classrooms. They cite specific PBL programs that resulted in learners who were more selfdirected, mastered essential content, were less threatened by the learning environment, and were more able to transfer learning across situations. The proposed benefits to classroom students' learning are diverse including helping students to engage in critical and creative reasoning, productive group collaborations, open-minded reflections and active learning (Hung, 2002). Nursing students engaged in case-based instruction consulted many sources including texts, class notes, the Internet, and professionals in the field before submitting a formal report describing their findings, recommendations, and rationale (DeMarco, Hayward, \& Lynch, 2002). This research suggests "that working with cases increases student confidence related to class material and working successfully with others" (DeMarco, Hayward, \& Lynch, 2002, pg. 170). In fact, case study instruction is associated with intrinsic motivation among both nursing and educational psychology students (DeMarco, Hayward, \& Lynch, 2002; Herman, 1998). Cases can be intrinsically motivating if they are realistic and personally relevant, and this in turn promotes selfdirected learning where activities are seen as valuable and interesting (DeMarco, Hayward, \& Lynch, 2002). 


\section{CRITICAL THINKING AND COMMUNITIES OF PRACTICE}

A current catch-phrase is to encourage students to become critical thinkers. Case studies offer the opportunity for students to engage in critical thinking (Grossman, 1994; Harrington, 1995). Critical thinkers gather and assess information, ask vital questions, come to conclusions, apply their learning to real contexts, and reflect on their learning (Paul \& Elder, 2001). In pre-service teacher preparation, case-based instruction "provides opportunities to marshal and evaluate evidence for judging alternative interpretations and actions..." (Harrington, 1995, pg. 204). Often instructors will offer case-based instruction during group activity such as group discussion or group projects. In Vygotsky's contextual theory the pathway to expertise is associated with immersion in a particular social situation over time with individuals acquiring skillful knowledge and the ability to engage successfully in the discourse, norms, and practices of the particular community of practice (Vygotsky, 1962). "Ambiguity surrounding the case and value judgments of the students foster good discussions and the search for better decision models. Cases encourage participation, debate, and understanding. Students attack cases from various viewpoints, differences in values and perceptions become obvious" (Grupe \& Jay, 2000, pg. 123). In particular, case studies help educational psychology students learn how to frame problems, understand the tacit knowledge they bring to such situations, and value multiple theories of action" (Herman, 1998). Lundeberg, \& Scheurman (1997) employed the use of case studies before and after units of instruction in Educational Psychology as a way to anchor understanding of theoretical concepts. They concluded that students' learning was affected by the case study by comparing their responses to the cases before and after instruction and that students benefit from repeated discussion of cases because it allows for novel problem solving and critical thinking, reorganization of ideas, and opportunities to evaluate others' viewpoints.

Another potential benefit of case-based instruction discussed by Harrington (1995), is the opportunity for prospective teachers to explore the multiple perspectives of diverse stakeholders in education. "One way to help students begin to see salient features is to encourage them to examine the dilemmas of teaching from a variety of perspectives" (pg. 208). Students, teachers, parents, and administrators might view a particular dilemma differently. Consideration for diverse perspectives can lead to more thoughtful action at the decision-making table. "Awareness of alternative perspectives is not only a key aspect of critical thinking but may be a necessary step to being able to reflect on and critique our own perspective and, when necessary, move beyond it" (pg. 209).

\section{TRADITIONAL OR WEB ENVIRONMENT}

Case-based instruction could easily be adapted to both the traditional classroom environment or via distance learning and web-assisted instruction. As stated previously, many instructors use case studies as a vehicle for classroom discussion. In the web environment, this discussion could take place on either synchronous or asynchronous discussion boards and chat rooms. Bonk, et al (1998) explored whether pre-service teachers' use of case studies via the web would impact their learning of educational psychology. The authors found many positive results with regard to the web, including students' diligent involvement in postings and communication, reciprocate interaction among many stakeholders such as students, instructors, cooperating teachers, as well as peer support and social acknowledgement. The critical ingredient may truly be the opportunity for dialogue and the exchange of ideas which can occur in either forum. However, insufficient research has been conducted to tease apart any potential differential outcomes across these two learning environments, and future research should begin to examine this possibility.

\section{REFERENCES}

1. Aspy, D.N., Aspy, C.B., \& Quinby, P.M. (1993). What doctors can teach teachers about problem-based learning. Educational Leadership, 50(7), 22-25.

2. Block, K. (1996). The "case" method in modern educational psychology texts. Teaching \& Teacher Education, 12(5), 483-500.

3. Bonk, J.C., Malikowski, S., Angeli, C., \& East, J. (1998) Web-based case conferencing for preservice teacher education: Electronic discourse from the field. Journal of Educational Computing Research, 19 (3), 269-306.

4. DeMarco, R., Hayward, L., \& Lynch, M. (2002). Nursing students' experiences with strategic approaches to 
case-based instruction: A replication and comparison study between two disciplines. Journal of Nursing Education, 41(4), 165-174.

5. Greenwood, G.E., Fillmer, H.T., \& Parkay, F.W. (2002). Educational Psychology Cases, $2^{\text {nd }}$ ed. Upper Saddle River, NJ: Merrill/Prentice-Hall.

6. Grossman, R.W. (1994). Encouraging critical thinking using the case study method and cooperative learning techniques. Journal on Excellence in College Teaching, 5, 7-20.

7. Grupe F.H. \& Jay, J.K. (2000). Incremental cases: Real-life, real-time problem solving. College Teaching, 48(4), 123-128.

8. Harrington, H.L. (1995). Fostering reasoned decisions: Case-based pedagogy and the professional development of teachers. Teaching and Teacher Education, 11(3), 203-214.

9. Herman, W.E. (1998). Promoting pedagogical reasoning as preservice teachers analyze case vignettes. Journal of Teacher Education, 49(5), 391-399.

10. Hung, D. (2002) Situated cognition and problem-based learning: Implications for learning and instruction with technology. Journal of Interactive Learning Research, 13(4), 393-415.

11. Lundeberg, M. N. \& Scheurman, G. (1997) Looking twice means seeing more: developing pedagogical knowledge through case analysis. Teaching and Teacher Education, 13(8) 783-79.

12. Paul, R. \& Elder, L. (2001). A Miniature Guide for Students on How to Study \& Learn: A Discipline Using Critical Thinking Concepts \& Tools. Dillon Beach, CA: The Foundation for Critical Thinking.

13. Pedersen, S. \& Liu, M. (2002). The effects of modeling expert cognitive strategies during problem-based learning. Journal of Educational Computing Research, 26(4), 353-380.

14. Vygotsky, L.S. (1962). Thought and language. (E. Hanfmann \& G. Vakar, Eds., Trans.) . Cambridge: The M.I.T Press.

15. Wright, A.E. \& Heeran, C. (2002). Utilizing case studies: Connecting the family, school, and community. School Community Journal, 12(2), 103-115.

\section{NOTES}

